\title{
首都圈における深部地質構造と地震活動
}

\author{
鈴木宏 芳*
}

I.はじめに

近年, 関東平野では, 墚層ボーリングや物理探 査による地下構造の調査研究が数多く行なわれて おり，地下深部の地質や物性の様相が明らかにさ れつつある。また，首都圈地域は直下で会合する プレートの複雑な相互運動により, 活発な地震活 動域となっており, 近い将来に大きな被害をもた らす地震の発生が想定されている。ここでは, 最 近の研究で明らかになった首都圈地域の深部地質 構造や地震活動の特徵, 両者の関連等について, 紹介と解説を行なう。

\section{II. 深部地質構造}

\section{1）研究の経緯}

関東平野の深部構造の本格的な研究は, 昭和 30 年代に資源開発を目的として始められた。石井 （1962）によって，先新第三系の梁度分布が始め て提案され, 最深 $3,000 \mathrm{~m}$ を超える深度が推定さ れた。その後, 層序試錐や天然ガス開発, 地盤沈 下観測井の掘削等によって, 平野中央部では基盤 深度が実際に $3,000 \mathrm{~m}$ を超すことが確認された （垣見ほか, 1973）。1970年代には, 地震観測を目 的として国立防災科学技術センター（現防災科学 技術研究所）により 3 本の $3,000 \mathrm{~m}$ 級深層観測井 が掘削され, 多種の物理検層が実施された結果, 地下深部までの物性が明らかになった。

物理探査に関しては, 1960 年代から重力探査や 地震探査が行なわれてきたが，本格的に行なわれ るようになったのは 1970 年代からで, ブーゲー
異常に基づく基盤深度の推定（駒沢 - 長谷川， 1988）や，屈折法地震探査による基盤深度分布 （纐縝，1995）が提案された。1980 年代になると 反射法地震探査が深部調査に用いられるようにな り, 東京湾（加藤，1984）や平野中央部（笠原ほ か, 1994 他）で実施され，成果をあげた。また， 構造の良くわかった観測井近傍で反射探査を行な うことにより，反射構造と地質構造との関連が明 らかになり，反射法探査の精度向上が進められた。 1990 年代からは, 防災科学技術研究所により首 都圏地域の地震観測能力の向上のため, 首都圈周 辺で $3,000 \mathrm{~m}$ 級および $2,000 \mathrm{~m}$ 級の観測井が 15 本 掘削され，基盤深度分布が提案される（鈴木， 1998）等, 地下のデータの集積が進む一方，反射 法による活断層や堆積平野の構造調査等の, 地震 防災を目的とした研究が各機関や自治体により積 極的に行なわれるなど, 本地域の地下構造の調査 研究は着実に進んでいる。

\section{2）地質構造}

図 1 に上記の諸データを総合して作成した先新 第三系基盤の深度分布を示す。北緯 $35^{\circ} 30^{\prime}$ 付近 から南側には基盤に到達した孔井がないので，北 側に比べるとその信頼性は低いと考えられる。基 盤の起伏は地表の平坦さと比べて非常に凹凸に富 んでおり，最深部は房総半島中部で $4,000 \mathrm{~m}$ を超 え, 神奈川東部, 利根川中流域, 埼玉東部などで も $3,500 \mathrm{~m}$ 以上の深さになると推定される。基盤 の谷底部は利根川中流域から埼玉県東部に達し， そこで南に向きを変えて神奈川県東部に至り，さ らに東に変じて房総半島に続くクランク状の構造

\footnotetext{
* 防災科学技術研究所

本稿は 1999 年 2 月 19 日に行なわれた講演内容をまとめたものである.
} 


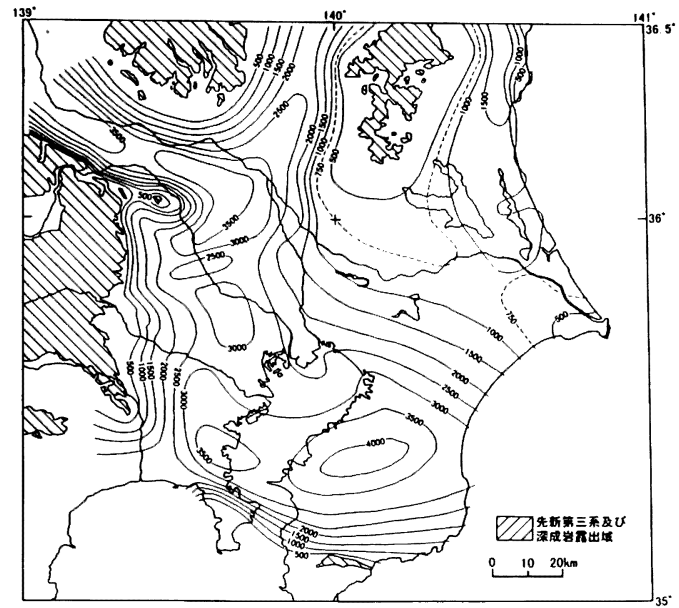

図 1 先新第三系基盤上面の深度分布 $(\mathrm{m})$.

を呈する。関東山地縁辺部では平野部下への基盤 の落ち込みは急激であり，特に北縁部で著しい。 筑波山地西縁部でもやや急な落ち込みがある。そ のため, 利根川中流域や鬼怒川流域では底の広い 非対称形の谷地形を呈する。埼玉南東部には，周 囲よりも約 $500 \mathrm{~m}$ 高い盛り上がりが存在する。平 野北東部の基盤構造は西側に比べて緩やかな形状 を呈する。これらの基盤構造は, 重力のブーゲー 異常によく反映されている。

図 2 は関東地域に広く分布する, 後期鮮新世か ら前期更新世の地層（上総層群およびその相当層） の基底深度分布を示す。房総半島の付け根付近を 中心にして, 関東平野の輪郭にほぼ沿うような, 太平洋側に開いた箱状の構造を呈する。最深部は 房総半島の北部で, 深さは $2,000 \mathrm{~m}$ を超えると推 定される。基盤の構造と比べて非常に単純であり, 反射法探査の結果を見ても反射面はほほ水平で, その堆積構造は単純であることがわかる。本層は 関東山地縁辺などを除きほとんど海成層で, 関東 平野の大部分が海化した時期の地層である。

図 1 と図 2 の間に分布する地層の堆積年代は中 新世から前期鮮新世となる。基盤層の凹凸とよく 類似した構造を呈し，基盤の凹凸を埋めるように 堆積したものと考えられる。基盤直上の地層の微 化石年代は，平野中央部や北部域では $16 \mathrm{Ma}$ 程度 であるが, 東京南部や東京湾北部では $10 \mathrm{Ma}$ 以後

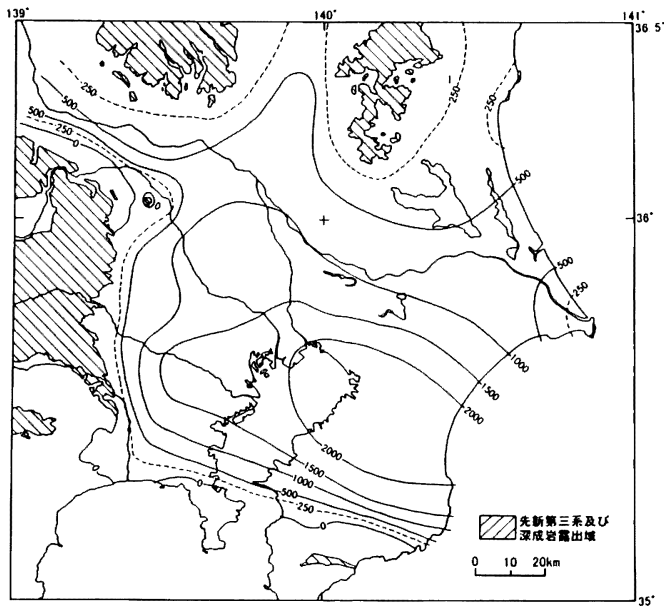

図 2 上総層群および相当層の基底深度分布 $(\mathrm{m})$.

であり，地域による堆積開始時期の違いが大きい。 反射波の構造を見ると、下部ほど構造が複雑であ る。これらの地層の堆積年代や構造の地域的な相 違などは, 関東平野の成因や構造発達に大きく関 係するものと考えられる。

\section{III. 首都圏の地震活動および地質構造との 関係}

首都圈地域は，直下で会合するプレートの複雑 な相互運動を反映して地震活動が非常に活発で, 江戸時代からしばしば大地震に襲われており，近 い将来にも発生すると想定されている。江戸時代 以降の地震の発生状況を見ると活動期と非活動期 が繰り返されており，現在は活動期に入りつつあ ると考えられている。

一方, 首都圈地域は新第三紀以降の軟弱な堆積 層が厚く分布している上に，社会的活動に伴う振 動が著しいため, 高感度地震観測は通常の方法で は困難であり, 地震研究は他地域に比べて遅れて いた。そのため, 防災科学技術研究所では, 振動 の少ない基盤の中まで孔井を掘削し，その中で観 測を行なうという深層地震観測システムを開発し 実用化した。この方法を用いて首都圈で高感度地 震観測が開始されたのは 1973 年以降であり, 高 感度地震データの蓄積は約 20 年にすぎない。 1996 年から始まった相模トラフ海域のケーブル式 


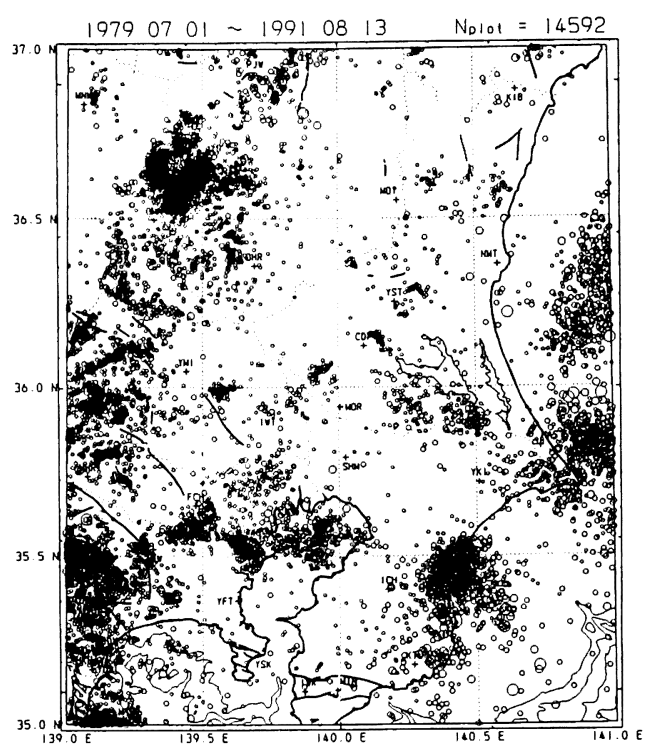

図 3 深さ $30 \mathrm{~km}$ よりも浅い地震の震央分布. 実線は活断層を示す。

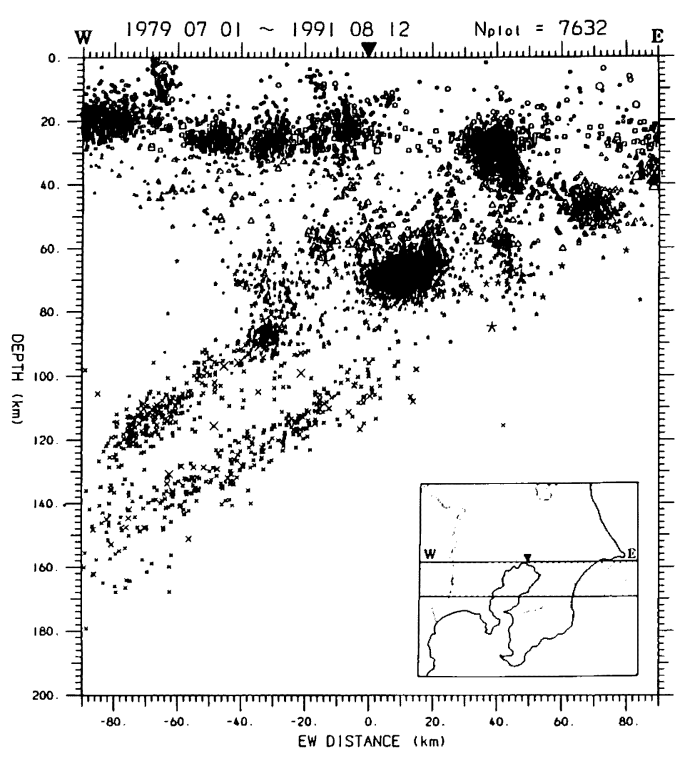

図 4 東西断面の震源分布. 右下の網目部分の地震を示す.
海底地震観測は、プレート沈み込み帯の地震活動 状況を精密に観測するものとして，その成果が期 待されている。

首都圏に被害をもたらした過去の大地震の震源 位置や発生様式等は, 一部を除き解明が進んでい ない。今後発生が予想される地震がどのような発 生様式なのかを明らかにすることは, 今後の予知 や防災上重要なことである。図 3 は $30 \mathrm{~km}$ よりも 浅い地震の震源分布を示す。首都圈周辺では, 東 京都・神奈川県境付近から東京湾北部に続く地域 や九十九里沿岸部, 霞ケ浦南方などで浅い地震が 活発である。また，関東山地や足尾山地でも活発 な活動が見られる。図 4 には首都圈付近を東西に 切る断面で示した震源分布を示す。太平洋プレー トやフィリピン海プレートの沈み込みに伴う地震 活動が明瞭に見られる。このような震源分布をも とに，沈み込むプレートの形状を 3 次元的に示す モデルが提案されてい（石田，1989他）。フィリ ピン海プレートの構造は研究者間でかなりの違い がある。今後データの蓄積により, 改良されるこ とが期待される。

本地域の地質構造と浅い地震活動との関連は,
必ずしも明らかではない。震源分布によれば，関 東山地や足尾山地等の山地部で浅い地震が多く, それに対し関東平野では $30 \mathrm{~km}$ よりも浅い地震は 限定された地域にのみ発生していることである。 浅い地款内地震の発生と大きな関係を有している と考えられるデー夕に地款熱流量がある。関東地 域の地殼熱流量の測定によると（鈴木，1991）, 山地部と平野部で地殼熱流量に大きな差があり, 熱流量の大きい山地部で浅い地震が多く，小さな 平野部で浅い地震が少ない傾向は明らかである。 平野部の中で, 地殼熱流量が比較的大きい部分で 浅い地震が多発していることは両者の関係を示唆 するものである。活断層の分布と浅い地震活動を 見ると, 活断層周辺では地震活動が低いように見 える。活断層の実体の解明と合わせて今後調査を 進める必要がある。

\section{IV. おわりに}

首都圈地域の深部地殼構造の解明は, その地域 的な重要性のため, 他の地域に比較してかなり進 んでいる。しかし, 房総など南部地域では基盤に 到達した深層試錐データが 1 本もないなど, 質量 
ともデータ不足である。基盤深部までの精密な地 質や物性を明らかにすることは, 地質構造や地震 発生場の研究のみならず, 地盤の震動性状など地 震防災に直接関係する研究への基礎的なデー夕を 提供するものである。今後, 基盤ボーリングや深 部反射探査等を含めた調査研究が進展することを 期待する。また, 海域を含めた高感度地震観測網 を充実させることにより, 地震発生様式やプレー 卜構造の解明等, 地震予知や地震防災のための研 究を一層進める必要がある。首都圏地域には, 公 表されているデー夕以外に，民間や公共団体等で 実施した未公表ボーリングデータや物探データが 多数存在する。このようなデータの概要でも研究 者等に公表されれば, 本地域の地質構造等の研究 に多大の貢献をなすものと考えられる。

\section{文献}

石田瑞穂 (1989): フィリピン海プレート北端部でのプ レート沈み込み, その 2 . 日本地震学会講演予稿集, 1989, No. 1, 46.

石井基裕（1962）:関東平野の基盤．石油技術協会誌，27， 615-640.

垣見俊弘・衣笠善博·木村政昭編（1973）：後期新生代 地質構造図。地質調査所.

笠原敬司 - 山水史生 - 井川 猛 - 足立幾久 (1994)：関 東平野トランセクト. 日本地震学会講演予稿集, 1994 , No. 2, 380 .

加藤 茂 (1984): 東京湾におけるマルチチャンネル反 射法探査. 水路部研究報告, 19,1-57.

頝攧一起 (1995): 首都圈の地下構造. 物理探査, 48 , 504-518.

駒沢正夫・長谷川 功 (1988): 関東地方の重力基盤に 見える断列構造. 地質学論集, 31，57-74.

鈴木宏芳 (1991): 関東平野南西部の浅発地震活動と地 殼構造. 日本地震学会講演予稿集, 1991, No. 2, 17. 鈴木宏芳 (1998): 関東平野の基盤構造. 日本地震学会 講演子稿集, 1998, No. 2, B81. 


\section{モンゴロイドの起源と日本人}

\section{馬場 悠 男*}

\section{I. 現生人類諸集団 (人種?) の形成}

世界の人類は，コーカソイド・ニグロイド・モ ンゴロイド・オーストラロイドという 4 つの人種 に分けられてきたが，人種差別につながることが あるので, 最近ではそれぞれヨーロッパ人・アフ リカ人・アジア人・オーストラリア人と呼ぶこと が多い。さらに，人種という概念自体が崩壊した と考える研究者も多い。典型的なモンゴロイドの 身体特徵は, 淡褐色の皮膚・短一中身長・胴長短 足·丸い頭・平坦な顔面・ 一重瞼 - 黑色直毛・薄 めの体毛などである。

最初の人類である猿人は数百万年前にアフリカ で誕生し，2 百万年ほど前に原人に進化した。原 人は，百万年以上前にアフリカを脱出し，アジア． ヨーロッパに広がった。そして，世界各地の環境 に適応し，地域性を大なり小なり保有した集団と して進化した（図 1)。その地域性がそのまま現在 の人種変異を反映しているというのが,「多地域 進化説」あるいは「並列燭台モデル」といわれる 旧来の考え方である。すなわち，私たちモンゴロ イドは数十万年以上前のジャワ原人や北京原人の 子孫ということになる(図 2)。

それに対し，およそ十数万年前にアフリカで最 初の新人が誕生し, 彼らが世界中に広がって, 各 地の原人の子孫を滅ほしたというのが,「新人ア フリカ起源説」あるいは「ノアの箱舟モデル」と いわれる新しい考えである。それによると，現代 人類集団の変異はわずか十万年たらずの環境適応 の結果ということになり，モンゴロイドは少し前
まではニグロイドだったことになる。また，オー ストラロイドの古代的風貌は，5１0 万年ほど前 の人類の姿をかなり濃く保っていると解釈できる。 分子遺伝学的な研究では, 世界中の現代人の系 統はかなり新しいというデータが大量に得られて， 「新人アフリカ起源説」を補強している。化石の 形態研究では, 少なくともヨーロッパに関しては, ネアンデルタール人は絶滅し，アフリカから来た クロマニヨン人が現代ヨーロッパ人になったと考 えられている。ただしアジアに関しては，5１0 万年ほど前の化石発見例が少ないのでよくわから ない。

\section{II. 縄文人と弥生人は何処から来たか}

日本列島で発掘される人骨の形態を調べると， 縄文時代と弥生時代とのあいだに大きなギャップ がある。すなわち，縄文人は立体的な顔立ちで四 肢の末端が相対的に長かった。それに対し，弥生 人あるいは古墳人などは平坦な顔立ちで四肢の末 端が相対的に短かった（図 3，4）。

縄文人の特徽は, 今日の南方アジア人によく見 られるので, 彼らは南方からやってきたと考えら れがちである。だが, 縄文人の特徵は古くから北 東アジアおよび東南アジアにかけて住んでいたモ ンゴロイドに共通する特徴であり，縄文人はもと もと日本列島あるいはその周辺に住んでいたと考 えた方がよい。なお，沖縄で発見された更新世末 期の港川人は, 頭蓋の特徽は縄文人と似ているが 四肢骨の特徵は縄文人とは違っているので, 縄文 人の祖先かどうかわからない。

* 国立科学博物館人類研究部

本稿は 1999 年 4 月 20 日に行なわれた講演内容をまとめたものである. 


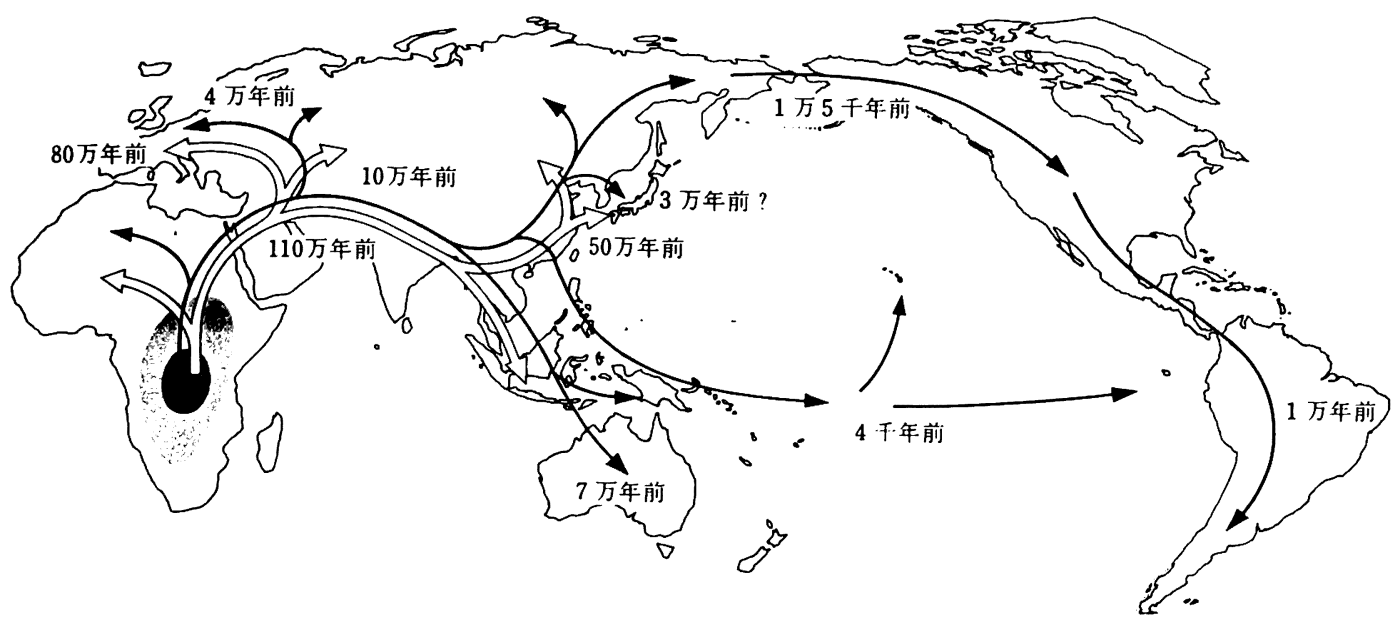

図 1 人類の拡散.

原人の時代と新人の時代に 2 度の拡散が起こったらしい.

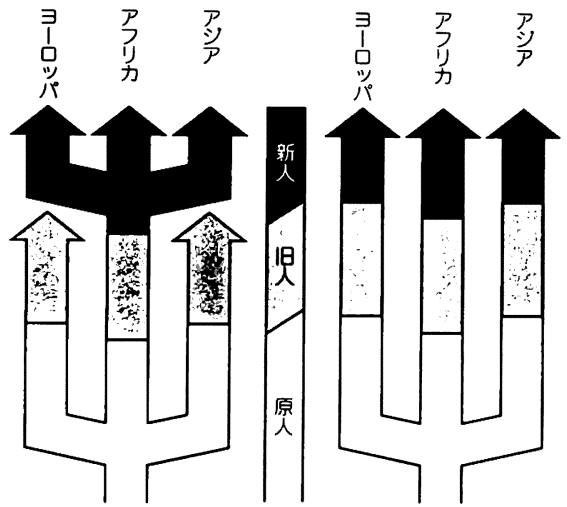

図 2 新人アフリカ起源説（左）と多地域進化説 (右).（山口 敏による）

弥生人の身体特徵は, 今の北方アジア人にもよ く見られ，最近 2３万年ほどの間にシベリアで 厳寒の気候に適応して形成されたと推測されてい る(表 1 )。すなわち, 体熱の発散を防ぐため, 胴 長短足で四肢の末端が短くなった。凍傷にならな いためには顔の突出部が少ないほうがよいので， 鼻が低く平坦な顔かたちが生まれた。また，皮下 脂肪を厚くしたために，一重瞼になった。息がツ

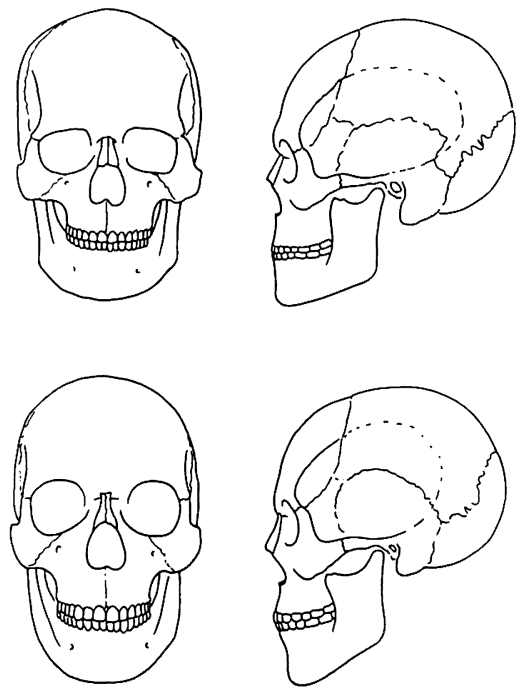

図 3 縄文人男性頭蓋（上）と弥生人. 男性頭蓋（下）の比較.

ララになって着くのを防ぐために，眉や影が疎ら になった。それに伴い，体毛とそれに付随するア ポクリン腺がが減ったので, 腋臭が弱く耳垢が乾 くようになったらしい。唇も，粘膜の反転部分で 皮下脂肪がないために凍傷になやすいので，薄く 


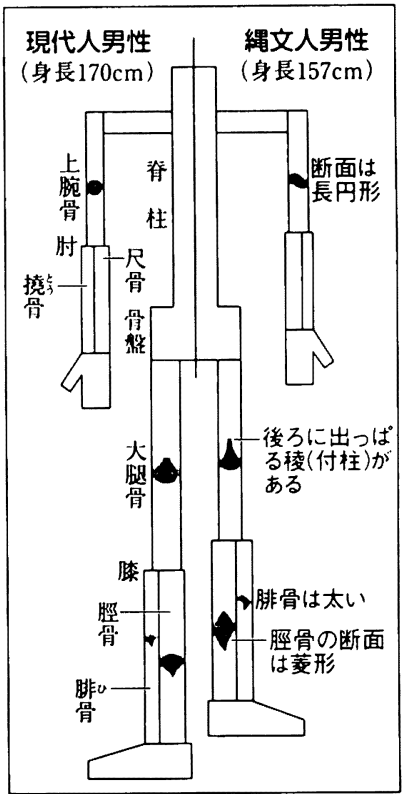

図 4 縄文人男性（右）と現代人男性（左） の体格比較模式図.

なったのだろう。凍った肉を食べたり，生皮を噛 んで鞣すために，歯が大きくなった，等々。もち ろん, 生きている人の顔が変わったのではなく, そのような個体が選択されて，集団として特徵が 変わったという意味である（表 1 )。

\section{III. 現代日本人は弥生人の影響が強い}

寒冷適応を遂げた北方アジア人たちは，その後， 北東アジア全域に広がり，2,300 年前には日本列 島に侵入してきて弥生時代の幕を開けることになっ た。すなわち, 彼らこそ(渡来系) 弥生人に他な らない。弥生時代以降, 弥生人と縄文人（の子孫） との混血が進んだが、日本全体としては弥生人の 影響が強かった。これは, 単純に弥生人が大量に
表 1 认方市方南方系縄文人と北方系弥生人の 身体特徵比較

\begin{tabular}{|c|c|c|}
\hline 身体特徵 & 南方系縄文人 & 北方系弥生人 \\
\hline 顔形 & 四角／長方形 & 丸 / 楕円 \\
\hline 造作の線構成 & 直線 & 曲線 \\
\hline プロフィル & 凸凹 & なめらか \\
\hline 彫りの深さ & 立体的 & 平坦 \\
\hline 眉 & 太い/濃い/直線 & 細い/薄い/半円 \\
\hline 影 & 濃い/多い & 薄い／少ない \\
\hline 瞼 & 二重 & 一重 \\
\hline 顐骨 & 小さい & 大きい \\
\hline 耳たぶ & 大きい/福耳 & 小さい／貧乏耳 \\
\hline 耳垢 & 湿る／飴耳 & 乾く/粉耳 \\
\hline 鼻 & 広い／高い & 狭い/低い \\
\hline 唇 & 厚い & 薄い \\
\hline 歯 & 小さい & 大きい \\
\hline ロ元 & 引き締まる & 出っ張り気味 \\
\hline 四肢末端 & 長い & 短い \\
\hline 腋臭 & 有り & 無し \\
\hline 体毛 & 多い & 少ない \\
\hline
\end{tabular}

やってきたと考えるよりも, 組織的水田稲作生活 をしていた弥生人の人口増加率が採集狩猟生活を していた縄文人よりも高かったためと考える方が よい。また, 縄文人は弥生人が持ち込んだ麻疹や インフルエンザあるいは結核などの病気によって 多量に死亡したらしい。

古墳時代以降には, 混血はさらに進んだと考え られるが，現在でも地域的な違いは残っており， 関西を中心とする西日本では圧倒的に弥生系が強 く, 東北・北海道や南九州・沖縄では縄文系がや や強い。なお, アイヌの人々は縄文人の直系子孫 であることに疑問はないが, 最近では, 沖縄の人々 は弥生系の（あるいは中国から直接の）影響が強 いというデー夕も多い。 